Acta vet. scand. 1997, 38, 197-199.

Brief Communication

\title{
CAEV Infection does not Affect Prevalence of Bacterial Mastitis in Goats
}

Like other lentiviruses, caprine arthritis-encephalitis virus (CAEV) causes persistent infection. The majority of CAEV-infected goats is clinically healthy. Signs of disease are associated with progressive inflammation in one or more organ or tissue systems such as joints, bursae, brain, spinal cord, lungs, and udder (Bulgin 1990, Dawson 1987). In most CAEVinfected females, the mammary gland, which is a target for the virus, is likely to be infected (Kennedy-Stoskopf et al. 1985, Lerondelle et al. 1989). The infection may cause increased somatic cell counts (Post et al. 1984, Nord \& Adnøy to be published). The milk mostly appears normal and mastitis may not be suspected. Ryan et al. (1993) and Smith \& Cutlip (1988) suggested that susceptibility to bacterial udder infection is enhanced in CAEV-infected goats, in particular with regard to infections due to non-haemolytic Staphylococci. In this study, the prevalence of bacterial udder infections in CAEV-antibody positive goats is compared with that in negative animals.

Sera from 26 lactating goats in each of 17 herds were examined for antibodies against CAEV by an enzyme-linked immunosorbent assay (ELISA) (Rimstad et al. 1994). The goats were randomly selected according to the total age distribution in each herd, as described elsewhere (Nord et al. to be published). Simultaneously, milk was sampled aseptically once in late lactation, and submitted to the regional labora- tory. Routine bacteriological examinations on blood agar plates were performed (Anon. 1981, Anon. 1987b). Schalm's Test was performed on each milk sample to give an indication of somatic cell count (Schalm et al. 1971). A diagnosis of bacterial mastitis was based on a positive bacteriological finding combined with a Schalm's Test score of 3 or more (Anon. 1987a). Prevalences of bacterial mastitis in seropositive and seronegative lactating goats were compared using the Logistic Regression Model in the JMP software (SAS Institute Inc. 1995) for MSWindows, controlling for age, farm, and bacterial agent.

All tested herds and 199 (45\%) of the tested goats were positive for antibodies against CAEV. In all, $38(4.2 \%)$ out of 884 milk samples from 37 ( $8.4 \%$ ) out of 442 goats gave findings consistent with bacterial mastitis. Four yielded coagulase-negative Staphylococci (0.45\%), 32 yielded Staphylococcus aureus (3.6\%), while one sample yielded Esherichia coli $(0.1 \%)$ (Table 1$)$. Of the 36 goats with mastitis which yielded Staphylococcus species, 17 were positive and 14 were negative for antibodies against CAEV (Table 1). The statistical analysis did not reveal any association between CAEV-antibody status and bacterial mastitis.

The recorded prevalence, $8.4 \%$ of bacterial mastitis in the goats, distributed in all the 17 tested herds, is very low. This might partly explain why statistically significant differences 
Table 1. Number of goats with mastitis among 442 goats in 17 herds, and serological results of an ELISA for antibodies against caprine arthritis-encephalitis virus.

\begin{tabular}{lrrrrrrr}
\hline & \multicolumn{2}{c}{ Mastitis diagnosis } & & \multicolumn{3}{c}{ CAEV antibodies (ELISA) } \\
\cline { 2 - 3 } \cline { 6 - 7 } Bacteria & No. herds & No. goats & & Positive & Indeterminate & Negative \\
\hline Staphylococcus aureus & 15 & 32 & & 15 & 4 & 13 \\
Coagulase negative Staphylococci & 4 & 4 & & 2 & 1 & 1 \\
Escherichia coli & 1 & 1 & & & & 1 \\
\hline
\end{tabular}

between CAEV-antibody positive and negative animals were not found. The occurrence of bacterial mastitis was recorded on the basis of just one milk sample. Further sampling of milk at different times, preferably combined with registration of clinical signs, might have given a more accurate expression of the true mastitis status in the herds. Nevertheless, although the cumulative incidences of clinical mastitis during one year as recorded by the owners were not included in the study, as in quite a few cases a specific aetiological diagnosis was lacking, the existing data (not shown) did not indicate any differences in the cumulative incidences of bacterial mastitis between seropositive and seronegative herdmates. Indeed, if CAEV infection disposes for bacterial mastitis, especially with Staphylococci species, as suggested by Ryan et al. (1993) and Smith \& Cutlip (1988), the high overall prevalence of goats with antibodies against CAEV should have led to a higher prevalence of Staphylococcal mastitis.

Kjersti Nord, Department of Large Animal Clinical Sciences, Norwegian College of Veterinary Medicine, Oslo, Norway.

\section{Acknowledgements}

This work was kindly supported by Norwegian Dairies. Thanks are due to Dr. T. Lunder, Norwegian Dairies, for assistance in organizing milk sampling. I also wish to thank Dr. S. Waage, Central State Veterinary Laboratory, Norway, and the Regional State Veterinary Laboratories, for performing bacteriological examinations of milk samples.

\section{References}

Anonymous: Laboratory methods for use in mastitis work. International Dairy Federation: IDF Bull., Docum. 132, Brussel, 1981.

Anonymous: Bovine Mastitis. Definition and guidelines for diagnosis. International Dairy Federation: IDF Bull., Docum. 211, Brussel, 1987a.

Anonymous: Laboratorierutiner for mastittdiagnostikk ved Statens mastittlaboratorier. (Laboratory Routines for Diagnosis of Mastitis at National Mastitis Laboratories.) Oslo: State Veterinary Laboratories and Central Veterinary Laboratory, $1987 \mathrm{~b}$.

Bulgin MS: Ovine progressive pneumonia, caprine arthritis-encephalitis, and related lentiviral diseases of sheep and goats. Vet. Clin. North Amer., Food Anim. Pract. 1990, 6, 691-704.

Dawson M: Caprine arthritis-encephalitis. In Pract., Farm Pract. 1987, 8-11.

Kennedy-Stoskopf S, Narayan O, Strandberg JD: The mamary gland as a target organ for infection with caprine arthritis-encephalitis virus. J. comp. Path. 1985, 95, 609-17.

Lerondelle C, Fleury C, Vialard J: La glande mammaire: organe cible de l'infection par le virus de l'arthrite et de l'encéphalite caprine. (The mammary gland: target organ for infection with the caprine arthritis-encephalitis virus.) Ann. Rech. vét. 1989, 20, 57-63.

Post JE, Hinckley L, Duval M: Udder infections with CAE virus in goats. Proc. U. S. Anim. Hlth. Ass. 1984, 88, 262-263.

Rimstad E, East N, Derock E, Higgins J, Pedersen $N C$ : Detection of antibodies to caprine ArthritisEncephalitis virus using recombinant GAG proteins. Arch. Virol. 1994, 134, 345-356.

Ryan DP, Greenwood P, Nicholls PJ: Effect of caprine arthritis encephalitis virus infection on milk cell count and N-Acetyl-beta-Glucosaminidase activity in dairy goats. J. Dairy Res. 1993, 60, 299-306. 
SAS Institute Inc.: JMP Statistics and Graphics Guide, Version 3.1 Cary, NC: SAS Institute, 1995.

Schalm OW, Caroll EJ Jain NC: Bovine Mastitis. Philadelphia: Lea and Febiger, 1971.
Smith MC, Cutlip R: Effects of infection with caprine arthritis-encephalitis virus on milk production in goats. J. Amer. Vet. Med. Ass. 1988, 193, 63-7.

(Received October 5, 1996; accepted December 15, 1996).

Reprints may be obtained from: K. Nord, Department of Large Animal Clinical Sciences, Norwegian College of Veterinary Medicine, P.O. Box 8146 Dep., N-0033 Oslo Norway. 
